\title{
Expectable Earthquakes and Their Ground Motions in the Van Norman Reservoirs Area
}

By R. L. Wesson, R. A. Page,

D. M. Boore, and R. F. Yerkes

THE VAN NORMAN RESERVOIRS AREA, NORTHERN SAN FERNANDO VALLEY, CALIFORNIA

GEOLOGICAL SURVEY CIRCULAR $691-B$

Prepared on behalf of the Federal

Disaster Assistance Administration 


\section{CONTENTS}

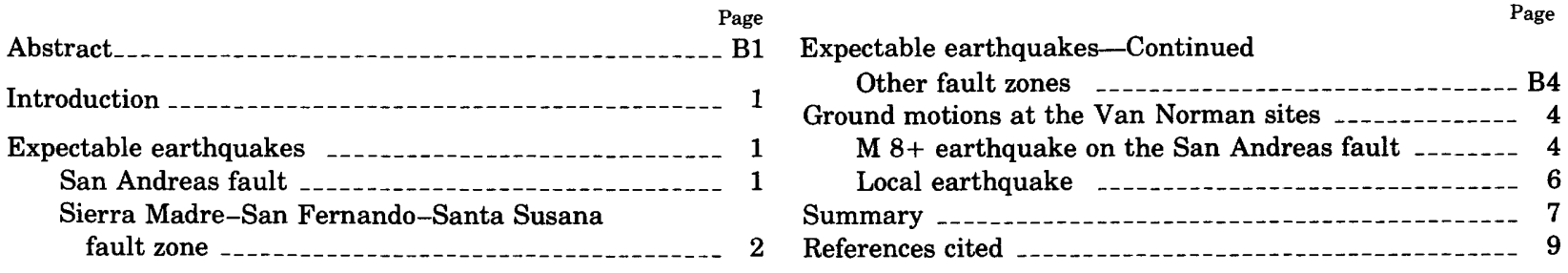

\section{ILLUSTRATIONS}

Figure 1. Vertical section through hypocenters of the 1952 Kern County and 1971 San Fernando earthquakes

2. Plot of peak horizontal acceleration versus distance to slipped fault as a function of magnitude

3. Plot showing estimate of response spectrum envelope for Van Norman sites, $\mathrm{M} 8 y_{2}$ earthquake on San Andreas fault

4. Plot showing estimate of response spectrum envelope for Van Norman sites, local earthquake of $\mathrm{M} 71 / 2$

\section{TABLES}

TABLE 1. Magnitude estimates for an assumed rupture length of $65 \mathrm{~km}(40 \mathrm{mi})$

2. Earthquakes of M 7 or more associated with shallow onshore reverse-slip and reverse-oblique slip faults

3. Expected values of horizontal ground motion for Van Norman sites 


\title{
THE VAN NORMAN RESERVOIRS AREA, NORTHERN SAN FERNANDO VALLEY, CALIFORNIA
}

\section{Expectable Earthquakes and Their Ground Motions in the Van Norman Reservoirs Area}

\author{
By R. L. Wesson, R. A. Page, D. M. Boore, and R. F. Yerkes
}

\begin{abstract}
The Van Norman reservoirs complex lies immediately upstream from a densely populated area. For this reason, the seismic stability of dams proposed for the complex should be analyzed on the basis of the worst seismic hazard that can reasonably be expected to affect the area. Accelerograms used in dynamic analyses to predict the response of the dam structures to earthquake loading should be chosen to (1) model the maximum expectable earthquakes from the tectonic province in which the dam is located and (2) adequately represent the ground motions expected at the damsites from those earthquakes. Two earthquakes are considered: a great earthquake in excess of M 8 on the San Andreas fault some $40 \mathrm{~km}$ (25 mi) northeast of the reservoirs area and a local earthquake of $M$ $71 / 2-73 / 4$ along the Sierra Madre-San Fernando-Santa Susana system of faults, within which the reservoirs area is located. The geologic and tectonic bases for expecting these earthquakes include an analysis of the seismic and tectonic history and environment of the Transverse Ranges of southern California. Basic parameters are suggested for the selection of accelerograms to model these two earthquakes, including suggested values for the peak horizontal acceleration, velocity, dynamic displacement, and duration.
\end{abstract}

\section{INTRODUCTION}

The Van Norman reservoirs area is within the Transverse Ranges of southern California, a region characterized by intense ongoing tectonic activity, which is responsible for a high level of seismicity and a history of damaging earthquakes. Because of the great potential for loss of life and for extensive property damage in the event of failure, we believe that the design of proposed dams should be analyzed in the light of the severest groundmotions that can reasonably be expected from earthquakes in the vicinity. In this report we analyze the earthquake hazard at the Van Nor- man site by considering two questions: What reasonably expectable earthquakes represent the most severe seismic hazard at the sites? What ground motions are reasonably expectable at the damsites from these earthquakes?

It is anticipated that proposed dams will be subjected to dynamic analyses in order to predict their performance under earthquake loading. Our purpose is to suggest criteria for the selection of accelerograms to be used as input for these analyses.

\section{EXPECTABLE EARTHQUAKES}

The maximum earthquake to be expected along a given fault zone can be predicted on the basis of (1) the seismic history of the fault zone, (2) the seismic history of the tectonic province, (3) a comparison with the seismic history of other fault zones in analogous structural and tectonic circumstances, and (4) magnitude-fault length relations. The two fault zones that appear likely to produce earthquakes accompanied by severe ground motions in the Van Norman area are (1) the San Andreas, some $40 \mathrm{~km}(25 \mathrm{mi})$ to the northeast and (2) the Sierra Madre-San Fernando-Santa Susana, within which the area is located.

\section{SAN ANDREAS FAULT}

A great earthquake (greater than $M$ 8) along the segment of the San Andreas fault nearest the Van Norman area unquestionably must be expected. Such an earthquake occurred in 1857, and there is every reason to believe that the processes responsible for that earthquake will continue into the foreseeable future. The magnitude of the 1857 
event is unknown, but from the length of faulting involved, it must have been at least as large as the 1906 San Francisco earthquake, M 8.3. Therefore, an earthquake in excess of M 8 must be anticipated.

\section{SIERRA MADRE-SAN FERNANDO- SANTA SUSANA FAULT ZONE}

Three historic earthquakes in the San Fernando area were capable of producing substantial damage:

1700's (1769?). Magnitude unknown. Bonilla (1974) describes evidence that one of the scarps resulting from the 1971 San Fernando earthquake is associated with a buried scarplike feature of even greater height that was formed about 200 years ago. This scarp may have been formed during the very large earthquake felt by the Portola expedition in 1769.

1893, Pico Canyon earthquake. About M 6 (C. R. Allen in Wentworth and Yerkes, 1971).

1971, San Fernando earthquake. M 61/2.

The magnitudes of all three earthquakes are estimated to be 6 or greater. The inferred major earthquake on the San Fernando fault zone about 200 years ago was associated with a scarplike feature

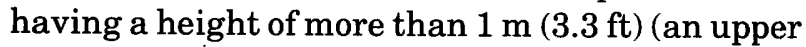
bound could not be determined) in Lopez Canyon, $61 / 2 \mathrm{~km}(4 \mathrm{mi})$ east of the reservoir area; this height is definitely greater than that of the 1971 fault scarp at the same locality $(0.9 \mathrm{~m}, 2.9 \mathrm{ft})$. Observations of the worldwide record indicate that fault displacements generally increase with earthquake magnitude (Bonilla, 1970; Bonilla and Buchanan, 1970); on this basis the earthquake that occurred about 200 years ago was larger than the 1971 earthquake of M 61/2 (Bonilla, 1974). Correlations based on the worldwide record indicate that the older partial scarp at Lopez Canyon corresponds to an earthquake of at least $M 63 / 4$, disregarding the distribution of displacement on one or more scarps. It is clear from even these limited data that the San Fernando earthquake is by no means a unique or isolated event, nor was it the largest possible.

The Transverse Ranges of California, in which the Van Norman sites are located, are characterized by geologic structure resulting from longestablished north-south compression, accompanied by intense and ongoing tectonic and seismic activity. The earthquakes in the Van Norman area, including the 1971 event, occur in response to the same tectonic forces, and in some cases in similar geologic circumstances, as other earthquakes in the Transverse Ranges area (see following list); some of them were significantly larger than the 1971 event.

Historic large earthquakes in the western Transverse Ranges area on faults other than the San Andreas ${ }^{1}$ (from Richter, 1958; Allen, 1971)

1812 (December 21), Santa Barbara Channel? Magnitude unknown but listed as "outstanding." Rossi-Forel intensity IX-X in Santa Barbara.

1852, Big Pine. Magnitude unknown, but may have been associated with surface rupturing.

1893, "Pico Canyon." About M 6.

1916, Tejon Pass. About M 6.0. (May have occurred on San Andreas fault.)

1925, Santa Barbara Channel. M 6.3.

1927, Off Point Arguello. M 7.5.

1952, Kern County. M 7.7. Three aftershocks greater than M 6 . The geologic-tectonic setting of this earthquake is analogous to that of the San Fernando earthquake.

1971, San Fernando. M 61/2. Surface rupturing.

1Earthquakes felt in the vicinity of the Santa Barbara Channel, and therefore pertinent to the Transverse Ranges, are described in detail by Hamilton, Yerkes, Brown, Buford, and DeNoyer (1969) and Lee and Vedder (1973).

A particularly apt analogy may be made between the 1971 San Fernando earthquake, south of the San Andreas fault, and the 1952 Kern County earthquake (M 7.7), north of the San Andreas fault. Both involved substantial reverse-slip and left-lateral strike-slip displacement along range-front faults that dip toward the San Andreas. Allen (1972), among others, has suggested that the stress system responsible for both the 1952 Kern County earthquake and the 1971 San Fernando earthquake is a result of the "great bend" in the San Andreas fault immediately north of the Transverse Ranges. The crustal block southwest of the San Andreas fault is moving northwestward - parallel to the general trend of the fault zone - relative to the crustal block northeast of the fault. The San Andreas fault opposite the Transverse Ranges trends more nearly westerly. In the area of this "great bend," the tectonic forces responsible for the movement of the crustal blocks - shearing along the generally northwestward-trending San Andreas fault zone - are resolved into north-south compression across the Transverse Ranges.

A schematic south-north cross-section offset along the San Andreas fault (fig. 1) clearly shows the symmetry of the White Wolf and San Fernando fault zones and the 1952 Kern County and 1971 San Fernando earthquakes. Each of these earth- 
N. $25^{\circ} \mathrm{E}$.

Section offset $80 \mathrm{~km}$

along San Andreas fault
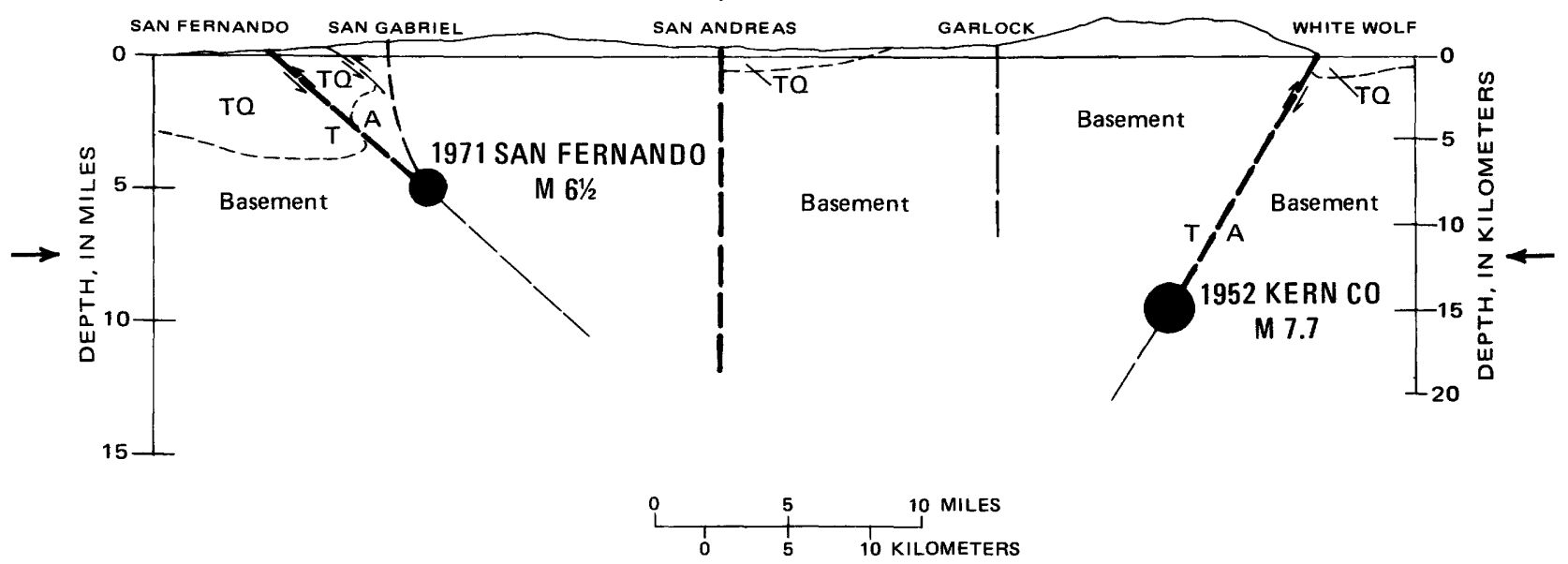

Figure 1.-Vertical section, offset $80 \mathrm{~km}$ along the San Andreas fault, through the hypocenters of the 1952 Kern County and the 1971 San Fernando earthquakes. Geologic units marked "TQ" consist of Tertiary and Quaternary sedimentary rocks. Symbols " $A$ " and "T" in-

quakes was generated by a sudden displacement - with both left-lateral and reverse components - along east-trending faults in response to stresses associated with the San Andreas system.

The magnitude of an earthquake appears to be empirically related also to the length of fault rupture in the earthquake (Bonilla and Buchanan, 1970). The maximum magnitude of an earthquake on a particular fault zone can thus be estimated crudely by assuming the maximum fraction of the total length that might rupture in a single earthquake. (See Wentworth and others, 1969.) It is difficult to apply this technique to the fault zone along the south margin of the Santa Susana and San Gabriel Ranges because of the complex relations of the faults as well as the complex nature of the faulting associated with the earthquakes, as demonstrated by the surface ruptures resulting from the 1971 San Fernando earthquake. Evidence has been presented for late Quaternary displacement along the south margin of the Santa Susana and San Gabriel Ranges, which extend from Oak Ridge (northwest of Santa Susana) to San Bernardino, a distance of some $130 \mathrm{~km}(80 \mathrm{mi})$ (Jennings and Strand, 1969; Proctor and others, 1970; Rogers, 1967; Wentworth and others, 1970; Wentworth and Yerkes, 1971). On the basis of observed magnitude-fault length relations, the dicate relative movements "away from" and "toward" the reader, respectively. Arrows at left and right margins indicate the general direction of lateral compression to which the earthquakes are attributed.

magnitude of the maximum event involving half this length, ${ }^{1}$ or $65 \mathrm{~km}(40 \mathrm{mi})$, would be about $71 / 2$ (table 1).

TABLE 1.-Magnitude estimates for an assumed rupture length of $65 \mathrm{~km}(40 \mathrm{mi})$

\begin{tabular}{|c|c|c|}
\hline $\begin{array}{l}\text { Relation between } \\
\text { magnitude }(M) \text { and } \\
\text { fault length }(L \text {, in kilometers) }\end{array}$ & Reference & $\begin{array}{l}\text { Estimated } \\
\text { magnitude }\end{array}$ \\
\hline $\begin{array}{l}M=0.76(\log L)+6.07 \\
M=0.9(\log L)+5.6 \\
M=2.91(\log L)+2.64\end{array}$ & $\begin{array}{l}\text { Iida (1965) } \\
\text { Tocher (1958) } \\
\text { Bonilla and } \\
\text { Buchanan (1970) } \\
\text { (all North } \\
\text { American data). }\end{array}$ & $\begin{array}{r}7.4 \\
-7.8\end{array}$ \\
\hline $\begin{array}{l}\text { Graph (lower dashed line in } \\
\text { fig. } 1 \text { of reference). }\end{array}$ & $\begin{array}{l}\text { Albee and Smith } \\
\text { (1967). }\end{array}$ & 7.8 \\
\hline
\end{tabular}

These estimates of magnitude-rupture length relations combined with (1) the seismicity of the Transverse Ranges, (2) the seismic history of the immediate area, (3) an ancient displacement on the San Fernando fault zone inferred to be larger than that of 1971 , (4) the analogy between the White Wolf fault zone (1952 Kern County earthquake) and the San Fernando fault zone, and (5) magnitude-fault length relations suggest that the 1971 earthquake (M 61/2) should not be accepted as

\footnotetext{
1This practice, although widely used, has little observational data to support it. Wentworth, Ziony, and Buchanan (1969) observed that the "ratio of length of rupture to length of the whole fault for about 10 historic North American events ranges at least from 0.02 to greater than 0.75 ." In view of this variation, the adopted ratio of 0.5 is not particularly conservative.
} 
the maximum that can be expected from this tectonic system, especially since this system has already produced one $M 7.7$ earthquake in this century. On this basis a local earthquake of at least $M$ $7 \frac{1}{2}-73 / 4$ is reasonably expectable.

Great earthquakes associated with reverse-type faulting are relatively common along the landward margins of ocean trenches (for example, Alaska, 1964, M 8.5; Chile, 1960, M 8.5). Large earthquakes also occur on onshore shallow reverse faults that are not primary plate boundaries (table 2 ). While perhaps less important in terms of plate tectonics, these earthquakes are nonetheless large enough to have severe consequences.

TABLE 2.-Earthquakes of $M 7$ or more associated with shallow onshore reverse-slip and reverse-oblique slip faults

[From Bonilla and Buchanan (1970)]

\begin{tabular}{|c|c|c|c|}
\hline Year & Location & Magnitude & $\begin{array}{l}\text { Length of } \\
\text { surface }(\mathbf{k m}) \\
\text { rupture }^{1}\end{array}$ \\
\hline $\begin{array}{l}1929 \\
1931 \\
1944 \\
1945 \\
1951 \\
1951 \\
1952 \\
1962 \\
1968 \\
1968\end{array}$ & $\begin{array}{l}\text { West Nelson, New Zealand } \\
\text { Hawkes' Bay, New Zealand } \\
\text { San Juan, Argentina } \\
\text { Mikawa, Japan } \\
\text { Meilun fault, Taiwan } \\
\text { Yuli fault, Taiwan } \\
\text { White Wolf fault, California } \\
\text { Buyin-Zara, Iran } \\
\text { Inangahua, New Zealand } \\
\text { Meckering, Australia }\end{array}$ & \begin{tabular}{l}
7.8 \\
\hdashline-7.9 \\
\hdashline-7.1 \\
\hdashline-7.3 \\
\hdashline-7.1 \\
\hdashline-1 \\
\hdashline-1
\end{tabular} & $\begin{array}{r}11 \\
10 \\
.7 \\
9 \\
7 \\
40 \\
53 \\
103 \\
1 \\
37\end{array}$ \\
\hline
\end{tabular}

The surface rupture lengths for several of these earthquakes are anomalously low in relation to their magnitudes (Bonilla and Buchanan, 1970, fig. 3). This may result from the poorly defined surface ruptures of such faults or from difficulties in investigating the individual faults (such as extension offshore).

\section{OTHER FAULT ZONES}

Other fault zones in southern California, such as the Santa Ynez, Newport-Inglewood, and Malibu Coast faults, and perhaps even the San Gabriel fault, must be considered capable of producing earthquakes at least comparable to the one discussed here for the Sierra Madre-San FernandoSanta Susana zone. In addition, many other faults should be considered capable of generating earthquakes as large as the 1971 earthquake (Wentworth and others, 1969). However, given the proximity of the Van Norman area to the Sierra Madre-San Fernando-Santa Susana and San Andreas fault zones, it is reasonable to accept the maximum expectable earthquakes on these two zones as an estimate of the worst seismic hazard that might affect the area.

\section{GROUND MOTIONS AT THE VAN NORMAN SITES}

\section{8+ EARTHQUAKE ON THE SAN ANDREAS FAULT}

To design a structure that will resist strong ground shaking, the expected ground motion must be described quantitatively. Strong ground motion can be described in terms of peak horizontal acceleration, velocity, displacement, and the duration of strong shaking. It would be ideal if there were direct observational data upon which to draw, but unfortunately no such data have been recorded closer than about $100 \mathrm{~km}$ (60 mi) to the causative fault of an M 8 or larger earthquake. Therefore, the ground motions in the Van Norman area from a great earthquake on the San Andreas fault, 25 $\mathrm{mi}$ to the northeast, must be modeled by a synthetic accelerogram that is selected or constructed on the basis of extrapolating available data and physical arguments, such as theoretical models of the earthquake source. The accelerogram should be characterized by parameters estimated from the best available data on peak horizontal acceleration, velocity, displacement, and duration of strong shaking ${ }^{2}$ as a function of distance from the causative fault. Existing observational data, critically reviewed and tabulated by Page, Boore, Joyner, and Coulter (1972), clearly indicate that for a given distance from the causative fault (for example, the distance from the San Andreas fault to the Van Norman reservoirs area, indicated by the vertical line $=40 \mathrm{~km}$ or $25 \mathrm{mi}$ ) the peak acceleration increases with magnitude (fig. 2). Thus, an earthquake in excess of $M 8$, at a distance of $25 \mathrm{mi}$, probably would produce a peak acceleration of 0.5 $g$ at the Van Norman site.

Page, Boore, Joyner, and Coulter, (1972, table 2) have estimated the peak horizontal acceleration, velocity, and dynamic or transient displacement on competent foundation materials near the causative fault for an M 8.5 earthquake; these values are $1.25 \mathrm{~g}, 150 \mathrm{~cm} / \mathrm{sec}(4.9 \mathrm{ft} / \mathrm{sec})$, and 100 $\mathrm{cm}(3.3 \mathrm{ft})$, respectively. The estimated peak velocity and transient displacement at the Van Norman sites, $40 \mathrm{~km}(25 \mathrm{mi})$ from the fault, are estimated at $60 \mathrm{~cm} / \mathrm{sec}(2.0 \mathrm{ft} / \mathrm{sec})$ and $40 \mathrm{~cm}(1.3 \mathrm{ft})$, assuming that they attenuate in the same proportion as the peak acceleration $(0.5 \mathrm{~g} / 1.25 \mathrm{~g})$. These values are compatible with the scanty data available. (See Page and others, 1972.) They are given in table 3, along with levels of acceleration exceeded or attained 2,5 , and 10 times and levels of velocity exceeded or attained 2 and 3 times.

\footnotetext{
${ }^{2}$ Page, Boore, Joyner, and Coulter (1972), comparing near-fault accelerograms with the felt reports, concluded that the phase of "intense" or "strong" shaking corresponds to accelerations of $0.05 \mathrm{~g}$ or greater. This definition is adopted in this report. This measure of duration does not always represent the total interval of time over which damage to structures and ground failure may occur (Seed and Wilson, 1967; McCulloch and Bonilla, 1970).
} 


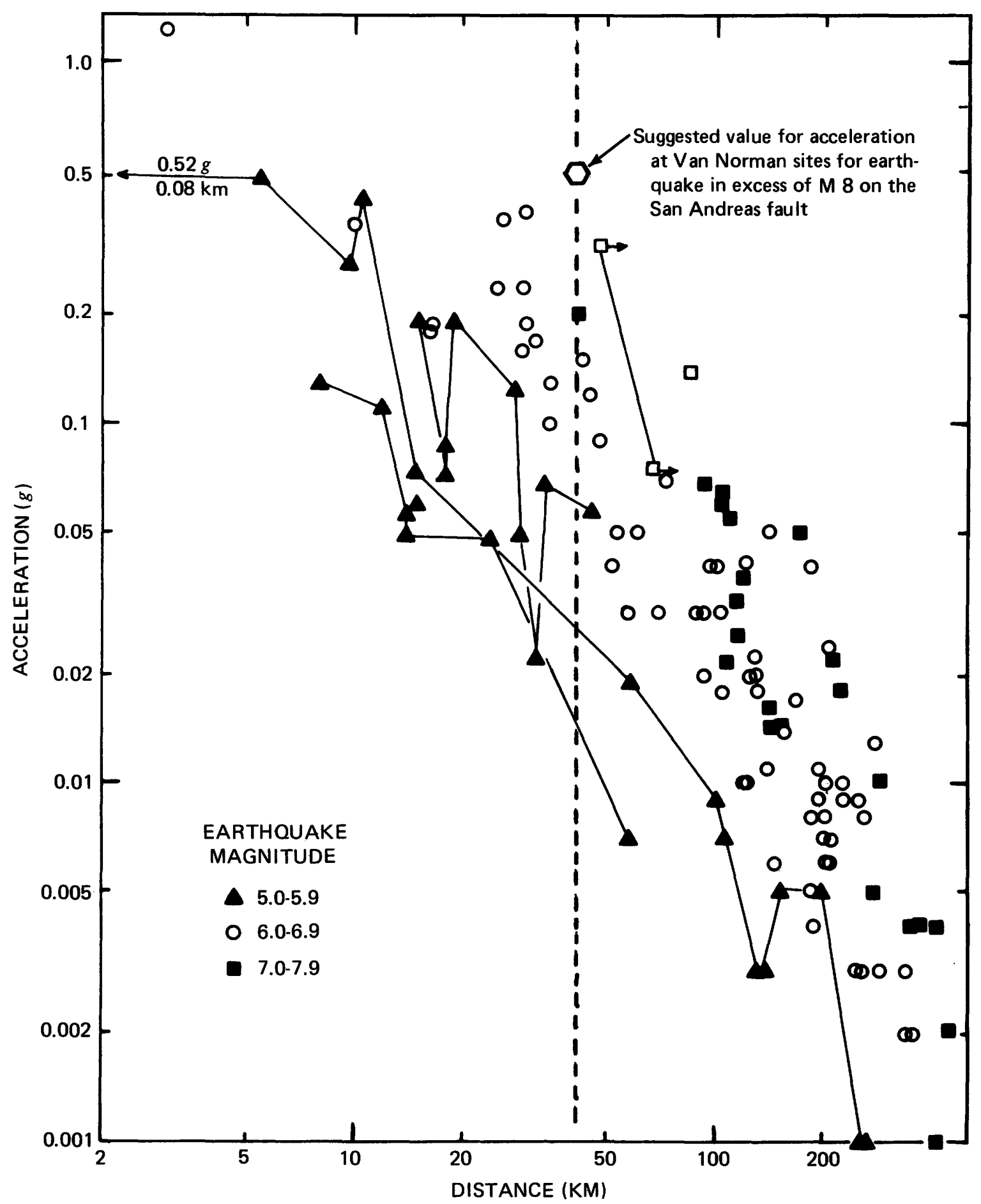

Figure 2.-Peak horizontal acceleration versus distance to slipped fault as a function of magnitude. Except for 1949 Puget Sound shock (open squares), data shown are those for which distances to fault are most accurately known. Straight-line segments connect observations at different stations for an individual earthquake, for three M 5 shocks, and one M 7 shock. From top to bottom, suites of M 5 data are from 1970 Lytle Creek $(\mathrm{M}=5.4)$, Parkfield $(\mathrm{M}=5.5)$, and 1957 Daly City $(\mathrm{M}=5.3)$ shocks. Closest Parkfield data point lies off plot

to left at $0.08 \mathrm{~km}$. For M 6, most data within $100 \mathrm{~km}$ are from 1971 San Fernando earthquake $(M=6.6)$, and most data beyond $100 \mathrm{~km}$ are from 1968 Borrego Mountain earthquake $(M=6.5)$. Most $M 7$ data are from $1952 \mathrm{Kern}$ County shock $(M=7.7)$. Open squares are values from 1949 Puget Sound event ( $M=7.1)$, for which distances are determined to hypocenter assuming minimum focal depth of $45 \mathrm{~km}$. Arrows denote minimum values. (From Page and others, 1972.) 
Current nonlinear dynamic analyses used in the design of structures require a time history of acceleration, an accelerogram, as input. Many accelerograms can be constructed with the parameters specified in table 3 , but it is essential that accelerograms used in the analyses not be deficient in energy at periods that are critical to the response of the particular structure. These critical periods are not generally known in advance of the analyses, because-if the response of the structure is nonlinear-they depend on the form and duration of the excitation.

It is necessary, therefore, to evaluate the frequency content of candidate accelerograms. To do this, a response spectrum envelope (fig. 3) was prepared, using the parameters specified in table 3 . This envelope can be compared with the response spectrum calculated from a candidate accelerogram. We introduce the response spectrum envelope as a method of determining whether or not candidate accelerograms have sufficient energy throughout the range of periods potentially critical to the particular structures. We do not propose that the response spectrum envelope replace dynamic analysis as a design tool. If only one accelerogram is used in the dynamic analysis, its spectrum should contain sufficient energy over the entire range of critical periods and have no significant excursions below the envelope. A suite of model accelerograms could also be used, which together would test the structure throughout the range of potentially critical periods.

\section{LOCAL EARTHQUAKE}

As discussed previously, an earthquake greater than $M \quad 7 \frac{1}{2}$ can reasonably be expected in the immediate Van Norman area. Criteria for selecting an accelerogram to model the ground motions from this local earthquake are derived as in the preceding section and are given in table 3 . Peak horizontal acceleration, velocity, displacement, and duration of strong shaking on competent foundation materials within $5 \mathrm{~km}$ ( $3 \mathrm{mi}$ ) of the fault causing an $\mathrm{M} 7.5$ earthquake are estimated to be $1.15 \mathrm{~g}$, $135 \mathrm{~cm} / \mathrm{sec}(4.43 \mathrm{ft} / \mathrm{sec}), 70 \mathrm{~cm}(2.30 \mathrm{ft})$, and $40 \mathrm{sec}$, respectively (Page and others, 1972, table 2). These values for acceleration, velocity, and duration are higher than those obtained from the record of the 1971 earthquake (M 61/2) at a seismoscope on the sedimentary bedrock that forms the east abutment of lower Van Norman dam (Scott, 1973).

Again, the frequency content of candidate accelerograms can be evaluated by means of an estimated response spectrum envelope (fig. 4), prepared using the values just given. Comparison of the estimated envelope with the response spectrum calculated for the Scott accelerogram indicates that the spectrum of the Scott accelerogram approaches the envelope for natural periods between about 1.5 and $7 \mathrm{sec}$ (with only minor "holes") but that it falls substantially below the expectable local earthquake envelope for periods less than about $1.5 \mathrm{sec}$, particularly in the range $0.2-1.5 \mathrm{sec}$.

One critical difference between the suggested parameters for the expectable local earthquake (greater than $M 71 / 2$ ) and the accelerograms recorded during the 1971 earthquake is duration. Although it does not enter directly into the response spectrum, duration is a controlling factor in the number of stress cycles a structure experiences. Accelerograms used to model a local earthquake of $M \quad 71 \frac{1}{2}$ or greater must therefore have an adequate duration of strong shaking (greater than $0.05 \mathrm{~g}$ ), at least $40 \mathrm{sec}$.

TABLE 3.-Expected values of horizontal ground motion for Van Norman sites

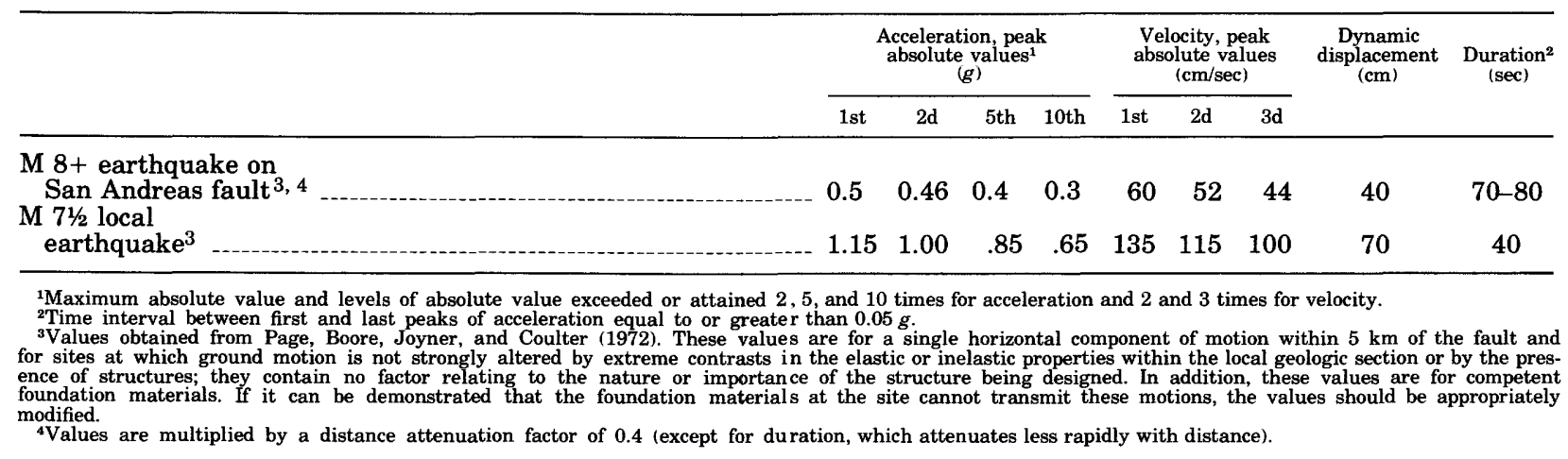




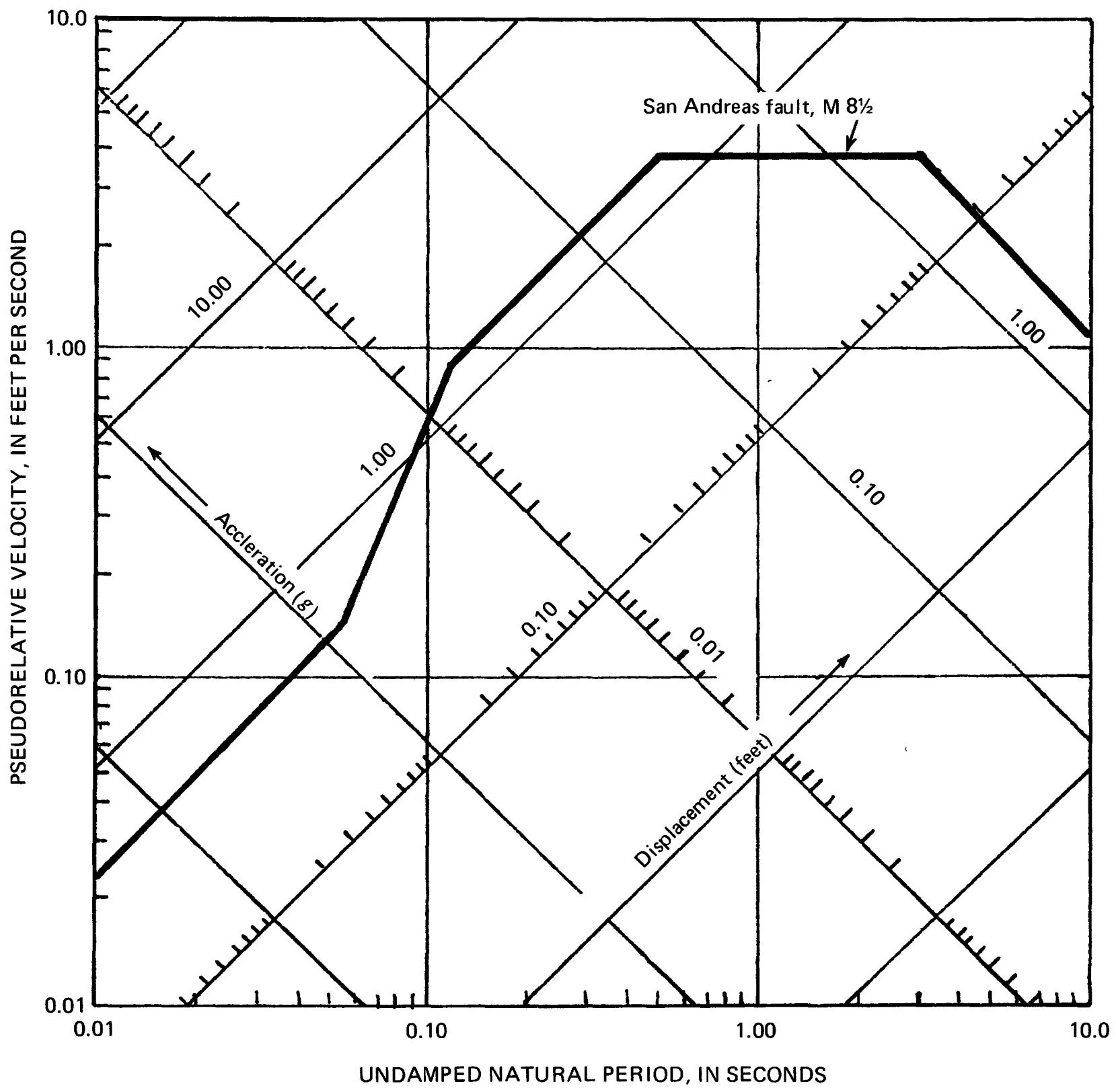

FigURE 3.-Estimate of response spectrum envelope (5 percent damping) for Van Norman sites, M $8 \frac{1}{2}$ earthquake on San Andreas fault; technique of Newmark and Hall (1969). (See Page and others, 1972, p. 15, for general discussion of response spectra and their derivation and Housner, 1970, for mathematical treatment.)

\section{SUMMARY}

The following values for peak horizontal acceleration, velocity, dynamic displacement, and duration are reasonably expectable effects, on competent foundation materials at the Van Norman sites, during an earthquake larger than M 8 along that segment of the San Andreas fault nearest the site: $0.5 \mathrm{~g}, 60 \mathrm{~cm} / \mathrm{sec}(2.0 \mathrm{ft} / \mathrm{sec}), 40 \mathrm{~cm}(1.3 \mathrm{ft})$, and $70-80 \mathrm{sec}$, respectively. (See table 3 .)
As regards a local earthquake, a tectonic system that has already produced one M 7.7 earthquake during historic time (1952 Kern County) must be considered capable of producing another; the Santa Susana-San Fernando-Sierra Madre fault zone, which forms the mountain front in the San Fernando area, is a probable locus for such an event, as indicated by the ancient large displacement in Lopez Canyon. Reasonably expectable 


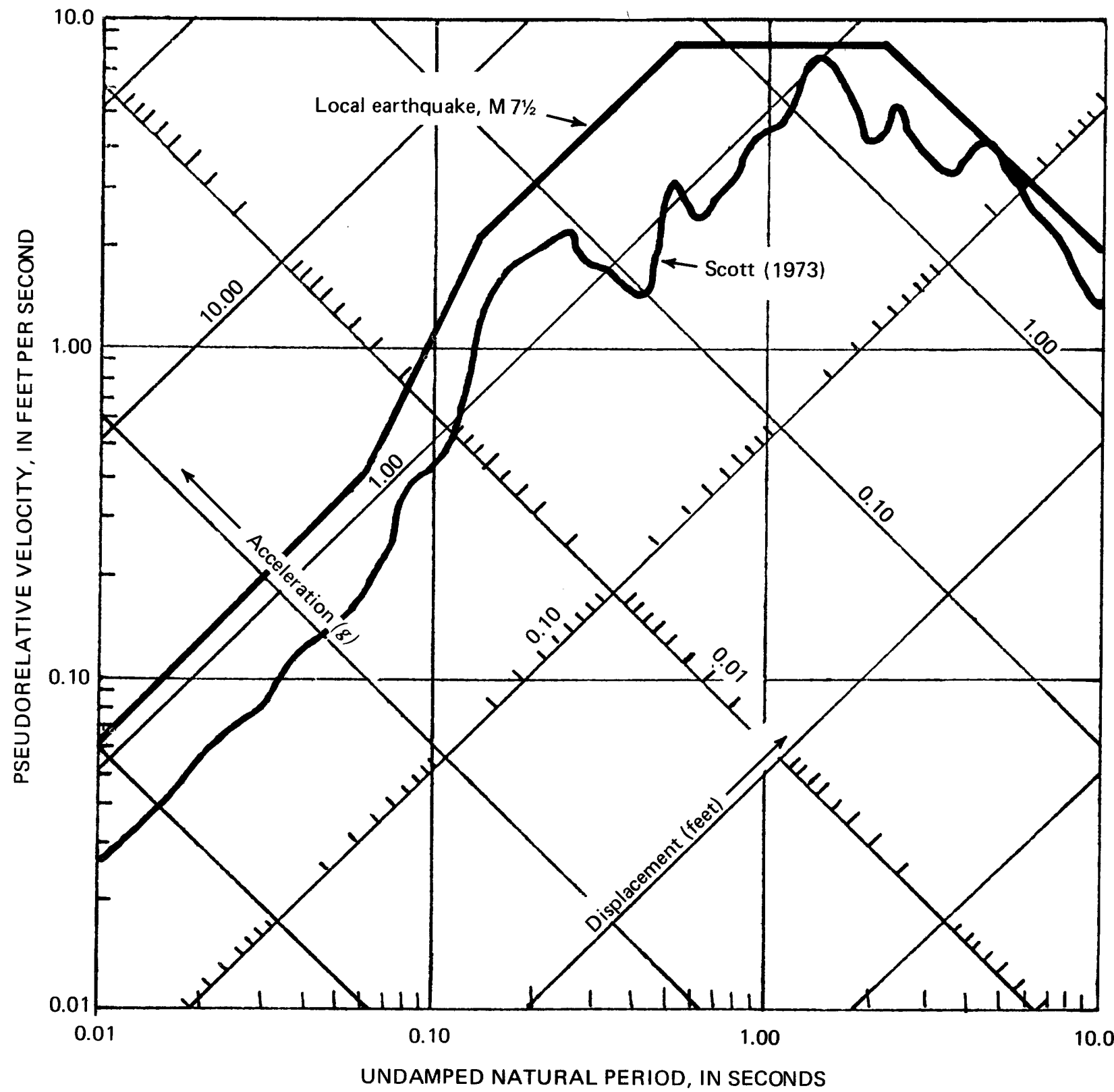

FiguRe 4.-Estimate of response spectrum envelope (5 percent damping) for Van Norman sites, local earthquake of $\mathrm{M} 7 \frac{1}{2}$; technique of Newmark and Hall (1969). Response spectrum of record obtained by Scott (1973) from seismoscope on east abutment of Lower Van Norman dam from the 1971 San

ground motions during such a local earthquake are characterized by peak horizontal acceleration, velocity, dynamic displacement, and duration at least as large as the following: $1.15 \mathrm{~g}, 135 \mathrm{~cm} / \mathrm{sec}$ $(4.43 \mathrm{ft} / \mathrm{sec}), 70 \mathrm{~cm}(2.3 \mathrm{ft})$, and $40 \mathrm{sec}$, respectively. (See table 3.)

Vertical ground motions also should be considered in the analyses, and accelerograms having
Fernando earthquake, also shown. (See Page and others, 1972 , p. 15, for a general discussion of response spectra and their derivation and Housner, 1970, for mathematical treatment.)

peak accelerations of at least two-thirds the peak horizontal values should be used for this purpose.

The response spectrum for an individual accelerogram might have "holes" at natural periods critical for the response of a particular structure, even though its peak values approach the desired envelope. Dynamic analyses should therefore be performed with a suite of accelerograms that have 
the same basic parameters but differ in detail, so that no period critical to the performance of the structure would go untested. If only one accelerogram is used to model each earthquake, then its spectrum should not show significant excursions below the estimated envelope.

\section{REFERENGES CITED}

Albee, A. L., and Smith, J. L., 1967, Geologic criteria for nuclear power plant location: Soc. Mining Engineers Trans., v. 238 , p. $430-434$.

Allen, C. R., 1971, Seismological environment, in Wentworth, C. M., and Yerkes, R. F., Geologic setting and activity of faults in the San Fernando area, California, in The San Fernando, California, earthquake of February 9, 1971: U.S. Geol. Survey Prof. Paper 733, p. 7, 10.

1972, Geological and seismological lessons, in Gates, G. O., ed., The San Fernando earthquake of February 9, 1971 and public policy: Special Subcommittee of the Joint Committee on Seismic Safety, California Legislature, July 1972 , p. $1-11$

Bonilla, M. G., 1970, Surface faulting and related effects, in Wiegel, R. L., ed., Earthquake engineering: Englewood Cliffs, N. J., Prentice-Hall, Inc., p. 47-74.

-1974 , Trench exposures of parts of the February 9, 1971, surface faults in the San Fernando fault zone, in Geological and Geophysical Studies, v. 3 of San Fernando, California, earthquake of Feb. 9, 1971: U.S. Dept. of Commerce-Natl. Oceanog. and Atmospheric Adm. (in press).

Bonilla, M. G., and Buchanan, J. M., 1970, Interim report on worldwide historic surface faulting: U.S. Geol. Survey open-file report, $32 \mathrm{p}$.

Hamilton, R. M., Yerkes, R. F., Brown, R. D., Jr., Burford, R. O., and DeNoyer, J. M., 1969, Seismicity and associated effects, Santa Barbara region, in Geology, petroleum development, and seismicity of the Santa Barbara Channel region, California: U.S. Geol. Survey Prof. Paper 679-D, p. 47-68.

Housner, G. W., 1970, Strong ground motion, in Wiegel, R. L., ed., Earthquake engineering: Englewood Cliffs, N.J., Prentice-Hall, p. 75-91.

Iida, Kumizi, 1965, Earthquake magnitude, earthquake fault and source dimensions: Nagoya Univ., Jour. Earth Sci., v. 13, no. 2, p. 115-132.

Jennings, C. W., and Strand, R. G., 1969, Geologic map of
California, Los Angeles sheet: California Div. Mines and Geology, scale 1:250,000.

Lee, W. H. K., and Vedder, J. G., 1973, Recent earthquake activity in the Santa Barbara Channel region: Seismol. Soc. America Bull., v. 63, no. 5, p. 1637-1661.

McCulloch, D. S., and Bonilla, M. G., 1970, Effects of the earthquake of March 27, 1964 on the Alaska Railroad: U.S. Geol. Survey Prof. Paper 545-D, $161 \mathrm{p}$.

Newmark, N. M., and Hall, W. J., 1969, Seismic design criteria for nuclear reactor facilities: World Conf. on Earthquake Eng., 4th, Santiago de Chile, 1969, Proc., v. 2, p. B4-37-B4-50.

Page, R. A., Boore, D. M., Joyner, W. B., and Coulter, H. W., 1972, Ground motion values for use in the seismic design of the trans-Alaska pipeline system: U.S. Geol. Survey Circ. $672,23 \mathrm{p}$.

Proctor, R. J., Payne, C. M., and Kalin, D. C., 1970, Crossing the Sierra Madre fault zone in the Glendora tunnel, San Gabriel Mountains, California: Eng. Geology-Internat. Jour., v. 4-1, p. 1-63.

Richter, C. F., 1958, Elementary seismology: San Francisco, W. H. Freeman, 768 p.

Rogers, T. H., 1967, Geologic map of California, San Bernardino sheet: California Div. Mines and Geology, scale $1: 250,000$.

Scott, R. F., 1973, The calculation of horizontal accelerations from seismoscope records: Seismol. Soc. America Bull., v. 63 , no. 5 , p. $1637-1661$.

Seed, H. B. and Wilson, S. D., 1967, The Turnagain Heights landslide, Anchorage, Alaska: Am. Soc. Civil Engineers Proc., Jour. Soil Mechanics and Found. Div., v. 93 (SM4), p. 325-353.

Tocher, Donald, 1958, Earthquake energy and ground breakage: Seismol. Soc. America Bull., v. 48, no. 2, p. 147-153.

Wentworth, C. M., Bonilla, M. G., and Buchanan, J. M., 1969, Seismic environment of the Burro flats site, Ventura County, California: U.S. Geol. Survey open-file report, 42 p. [1973].

Wentworth, C. M., and Yerkes, R. F., 1971, Geologic setting and activity of faults in the San Fernando area, California, in The San Fernando, California, earthquake of February 9, 1971: U.S. Geol. Survey Prof. Paper 733, p. 6-18.

Wentworth, C. M., Ziony, J. I., and Buchanan, J. M., 1970, Preliminary geologic environmental map of the greater Los Angeles area, California-TID-25363: U.S. Atomic Energy Comm., Springfield, Va., Clearinghouse Federal Sci. and Tech. Inf., 41 p., map scale 1:250,000. 
